\title{
Antitumor and immunomodulatory effects of polysaccharides from broken-spore of Ganoderma lucidum
}

\author{
Peng-Yun Wang, Xiao-Ling Zhu and Zhi-Bin Lin* \\ Department of Pharmacology, School of Basic Medical Sciences, Peking University Health Science Center, Beijing, China
}

Edited by:

Ricky Y. K. Man, The University of

Hong Kong, Hong Kong

Reviewed by:

Linghua Meng, Chinese Academy of

Sciences, China

Ricky Y. K. Man, The University of

Hong Kong, Hong Kong

*Correspondence:

Zhi-Bin Lin, Department of

Pharmacology, School of Basic

Medical Science, Peking University

Health Science Center, Beijing

100191, China.

e-mail: linzb1937@sina.com
The antitumor and immunomodulatory activity of broken-spore of Ganoderma lucidum polysaccharides (GI-BSP) were investigated in vivo and in vitro. It was showed that GI-BSP (50, 100 , and $200 \mathrm{mg} \mathrm{kg}^{-1}$ ) exhibited antitumor effect against Sarcoma 180 (S180) in BALB/C mice. The Gl-BSP was not cytotoxicity in S180 cells and PG cells (human lung carcinoma cell) in vitro. However, serum from G/-BSP-treated S180-bearing mice significantly inhibited S180 and PG cells proliferation in vitro. Moreover, GI-BSP promoted the splenic lymphocyte proliferation induced by Con A or LPS, enhanced nature killer cell (NK cell) cytotoxic activity, augmented the percentage of neutral red phagocytosis by macrophages, and increased the percentage of the $\mathrm{CD}^{+}$or $\mathrm{CD}^{+}$subset in S180-bearing mice. The serum level of IFN- $\gamma$, TNF- $\alpha$, and nitric oxide was increased by GI-BSP. GI-BSP also showed immunomodulatory activities in tumor-bearing mice. Furthermore, neutralization with anti-TNF- $\alpha$ and/or anti-IFN- $\gamma$ significantly diminished growth inhibition induced by GI-BSP-treated serum of S180-bearing mice in S180 or PG cells. These observations suggest that the antitumor activity of GI-BSP may be mainly related to the activation of the immune response of the host organism by the stimulation of NK cells, T cells, and macrophages.

Keywords: Ganoderma lucidum, spores, polysaccharide, antitumor activity, cytokines, lymphocytes, NK cells, macrophages

\section{INTRODUCTION}

Ganoderma lucidum (Leyss. et Fr.) Karst. (G. lucidum) is widely used in China and other oriental countries (Lin, 2001). G. lucidum (Lingzhi or Reishi) has been reported to be effective in modulating immune functions, inhibiting tumor growth (Sliva et al., 2002; Susan et al., 2002; Lin and Zhang, 2004), preventing oxidative damage (Kim et al., 1999; You and Lin, 2002), protecting liver, and reducing serum glucose levels, along with no toxicity (Zhang et al., 2002; Zhang and Lin, 2003).

Polysaccharides are one of active component of G. lucidum. Antitumor effects of polysaccharides isolated from G. lucidum were originally observed in sarcoma 180 bearing mice (Miyazaki and Nishijima, 1981; Sone et al., 1985). Recently, the antitumor effects of G. lucidum polysaccharides have been extensively investigated and were mainly through immune-related mechanisms (Xia et al., 1989; Sakagami et al., 1991; Wang et al., 1997, 2002; Hu and Lin, 1999; Yan et al., 1999; Zhang and Lin, 1999; Hsu et al., 2002, 2003; Wasser, 2002; Lee et al., 2003).

Recently, the spores of G. lucidum have attracted much attention for their versatile biological activities (Yang et al., 1997; Liu, 1999; Zhu et al., 2000; Liu et al., 2002; Lu et al., 2004). Bao et al. $(2000,2001 \mathrm{a}, \mathrm{b})$ has isolated several polysaccharides from broken or non-broken spores of G. lucidum, and proved these polysaccharides have immunomodulatory activities. The release ability of polysaccharides of broken spores has much greater than that of non-broken spores (Bao and Fang, 2001). In this study, we examined the antitumor activity of broken spore polysaccharides ( Gl-BSP) extracted from G. lucidum, and investigated the potential antitumor mechanism of $G l$-BSP.

\section{MATERIALS AND METHODS ANIMALS}

Inbred male 6-8 weeks old (body weight 18-22 g) BALB/c (H-2 d) mice (Grade II, Certificate No scxk11-00-0004) were purchased from the Department of Experimental Animals, Health Science Center, Peking University, Beijing, China. All procedures were in accordance to the Institute Ethical Committee for Experimental Use of Animals.

\section{CELL LINES}

Murine Sarcoma 180 cell lines (S180) were obtained from Beijing Tumor Institute. Human lung carcinoma cell lines (PG) and YAC-1 cell lines were provided by Department of Pathology and Immunology, Peking University Health Center. The cells were maintained in RMPI-1640 supplemented with $10 \%$ fetal calf serum (FCS) in a humidified environment at $37^{\circ} \mathrm{C}$ and $5 \% \mathrm{CO}_{2}$, and cultures were passaged every 2 or 3 days.

\section{DRUGS}

Gl-BSP was kindly provided by Fuzhou Institute of Green Valley Bio-Pharm Technology. It was a sandy beige water soluble powder and was isolated from boiling water extract of the broken-spore of G. lucidum (Leyss. et Fr.) Karst. (Gl), followed by ethanol precipitation, dialysis, and protein depletion using Sevag method. The purity of the Gl-BSP was $97 \%$, which was analyzed by high-performance liquid chromatography (HPLC). The component sugars and molecular-weight distributions of the glycopeptides were determined by gel permeation chromatography (GPC) and HPLC. The structures of the 
glycopeptides were detected by IR, ${ }^{1} \mathrm{H}$ NMR, and ${ }^{13} \mathrm{C}$ NMR. Gl-BSP had a molecular weight of 512,500 with a ratio of polysaccharides to peptides of $94.8: 5.2 \%$. The polysaccharides consisted of D-rhamnose, D-xylose, D-fructose, D-galactose, and D-glucose with a molar ratio of 0.549:3.614:3.167:0.556:6.89 linked together by $\beta$-glycosidic linkages. The peptides contained the following 16 amino acids: Asp, Thr, Ser, Glu, Gly, Ala, Cys, Val, Met, Ile, Leu, Phe, Lys, His, Arg, and Pro. GlBSP was dissolved in physiological saline for in vivo experiments or in serum-free RPMI-1640 (Gibco Laboratories, Grand Island, NY, USA) for in vitro experiments, filtered through a $0.22 \mu \mathrm{m}$ filter and stored at $4^{\circ} \mathrm{C}$ for future use. Endotoxins concentration in Gl-BSP samples were assayed under endotoxinfree experimental conditions by using a limulus amebocytes lysate chromogenic assay kit (Beijing BXGK Technology Development Co., Ltd., Beijing, China) according to the manufacture's instruction. The quantity of endotoxin in Gl-BSP was less than $0.01 \mathrm{EU} \mathrm{mg}^{-1}$, indicating that endotoxin contamination in Gl-BSP was negligible.

\section{ANTITUMOR EXPERIMENT IN TUMOR-BEARING MICE}

Murine Sarcoma 180 cell lines were injected into peritoneal cavity of mouse, proliferated there to produce ascites, and were maintained by weekly transplantation of the tumor cells from ascites into another peritoneal cavity of mouse. S180 were taken out from

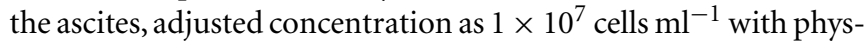
iological saline, and then injected in $0.2 \mathrm{ml}\left(2 \times 10^{6}\right.$ cells $)$ into the axillary fossa of a mice right foreleg to prepare tumor-bearing mice. The 50 mice were divided into five groups randomly (10 mice in each group) $24 \mathrm{~h}$ after the tumor inoculation and treated for 14 consecutive days with (1) low-dose Gl-BSP $\left(50 \mathrm{mg} \mathrm{kg}^{-1}\right)$ once daily by gavage, (2) intermediate-dose Gl-BSP $\left(100 \mathrm{mg} \mathrm{kg}^{-1}\right)$ once daily by gavage, (3) high-dose Gl-BSP $\left(200 \mathrm{mg} \mathrm{kg}^{-1}\right)$ once daily by gavage, (4) cyclophosphamide (CY, an antitumor agent, $30 \mathrm{mg} \mathrm{kg}^{-1}$ ) once every other day by intraperitoneal injection as positive controls, and (5) sterile physiological saline $\left(10 \mathrm{ml} \mathrm{kg}^{-1}\right)$ once daily by gavage as negative controls (model group), and the sixth group of normal mice administrated sterile physiological saline intragastrically once daily $\left(10 \mathrm{ml} \mathrm{kg}^{-1}\right)$ served as normal control.

After completion of treatment on the 14th day, the mice were killed and the tumors were removed and weighted. At the same time, blood samples were collected from the orbital vein and the serum was sterilized by filtration and preserved at $-70^{\circ} \mathrm{C}$.

\section{PG CELLS AND S180 CELLS PROLIFERATION ASSAY}

PG or S180 cells were maintained in RMPI-1640 supplemented with $10 \%$ FCS. A cell suspension $\left(2 \times 10^{7}\right.$ cell per liter $)$ was planted onto 96 -well plates $(0.1 \mathrm{ml}$ per well $)$, and incubated at $37^{\circ} \mathrm{C}, 5 \%$ $\mathrm{CO}_{2}$ for $24 \mathrm{~h}$. The media was replaced with $0.1 \mathrm{ml}$ of RPMI1640 supplemented with 5\% FCS and Gl-BSP 0.1, 1, 10, 100, or $400 \mathrm{mg} \mathrm{l}^{-1}$. In another series, RPMI-1640 was supplemented with $5 \% \mathrm{Gl}$-BSP treated serum 50,100, or $200 \mathrm{mg} \mathrm{kg}^{-1}$. After $48 \mathrm{~h}$, cells proliferation was estimated based on the cellular reduction of tetrazolium salt MTT by a microplate reader (BIO-RAD, Model 550), using a test wavelength of $540 \mathrm{~nm}$.

\section{PREPARATION OF SPLEEN LYMPHOCYTES}

Mice in all treated groups were killed and the spleens were aseptically removed, chopped with two slides and filtered over a fine nylon mesh to obtain single-cell suspensions. The cells were washed and lymphocytes were separated from red blood cells by Tris-HCl-buffered $\mathrm{NH}_{4} \mathrm{Cl}$ solution [mix 9 volumes of $0.83 \%$ $\mathrm{NH}_{4} \mathrm{Cl}$ with 1 volume of Tris- $\mathrm{HCl}$ (2.06\%, pH 7.65), adjust $\mathrm{pH}$ 7.2]. Cells were finally suspended in 10\% FCS RPMI-1640 supplemented with benzylpenicillin $100 \mathrm{kU} \mathrm{l}^{-1}$, streptomycin $100 \mathrm{mgl}^{-1}$ for further experiments.

\section{DETERMINATION OF PROLIFERATION OF LYMPHOCYTES}

Lymphocytes were planted into 96-well plates $\left(2 \times 10^{6}\right.$ cells per well) with or without ConA $1 \mathrm{mgl}^{-1}$ or LPS $5 \mathrm{mgl}^{-1}$, and incubated at $37^{\circ} \mathrm{C}, 5 \% \mathrm{CO}_{2}$ for $72 \mathrm{~h}$. Cell proliferation was estimated based on the method of MTT.

\section{SPLENIC NK CYTOTOXIC ACTIVITY ASSAY}

The NK cell activity of spleen cells was determined by a $4 \mathrm{~h}$ ${ }^{51} \mathrm{Cr}$-release assay. Viable trypan blue-excluded lymphocytes were counted. Cell survival rate was greater than 95\%. Target cells of YAC-1 were incubated for $1 \mathrm{~h}$ at $37^{\circ} \mathrm{C}$ with $\mathrm{Na}^{51} \mathrm{CrO}_{4}$ and were coated at a concentration of $1 \times 10^{4}$ cells per well in 96-well U-bottomed culture plates after washing. Effectors and targets were mixed at a ratio of $40: 1$ and incubated for $4 \mathrm{~h}$ at $37^{\circ} \mathrm{C}$. Spontaneous release was determined from wells that contained labeled target cells alone, and maximum ${ }^{51} \mathrm{Cr}$-release was determined by addition of $1 \%$ Triton X-100 (Sigma). The radioactivity of the supernatants was counted in $\gamma$-counter (Beckman LS 6500). Specific cytotoxicity was calculated as: percentage specific release $=100 \times(\mathrm{cpm}$ experimental release $-\mathrm{cpm}$ spontaneous release)/(cpm maximum release - cpm spontaneous release).

\section{NEUTRAL RED PHAGOCYTOSIS ASSAY OF PERITONEAL MACROPHAGES}

Macrophages were obtained from mice peritoneal exudates cells (PECs). PECs were washed twice and resuspended in a RPMI-1640 medium containing 10\% FCS. Peritoneal macrophages were further isolated from the PECs by incubating the PECs $\left(2 \times 10^{5}\right.$ cells per well) in a 96 -well plate at $37^{\circ} \mathrm{C}, 5 \% \mathrm{CO}_{2}$ for $4 \mathrm{~h}$ in a humidified atmosphere to allow peritoneal macrophages to adhere. The supernatants were discarded, and $0.075 \%$ Neutral red (NR) were added and incubated for another $1 \mathrm{~h}$. Cells were then washed with PBS for three times to remove excess dye and incubated with cell lysis buffer ( $1 \mathrm{M}$ acetic acid: ethanol=1:1) overnight. The absorbance (OD) was measured at $540 \mathrm{~nm}$ in a microplate reader (BIO-RAD, Model 550) and translated into phagocytosis ratio for comparison: phagocytosis ratio $=$ test $_{\mathrm{OD}} /$ normal control $_{\mathrm{OD}} \times 100 \%$.

\section{MEASUREMENT OF SPLENIC T LYMPHOCYTE SUBPOPULATIONS}

The cell concentration of lymphocytes was adjusted to $1 \times 0^{7} \mathrm{ml}^{-1}$. A volume of $20 \mu \mathrm{l}$ of FITC-labeled anti-mouse CD4 and $20 \mu \mathrm{l}$ of PE-labeled anti-mouse CD8 was added to $100 \mu \mathrm{l}$ of the cell suspension. After incubation for $30 \mathrm{~min}$ at $4^{\circ} \mathrm{C}$, the lymphocytes were rinsed three times with $1 \mathrm{ml}$ of $\mathrm{PBS}, \mathrm{pH} 7.4$, containing $0.5 \%$ BSA and $0.1 \% \mathrm{NaN}_{3}$. CD4 and CD8 T-cell 
subpopulations were analyzed by flow cytometry using a FACS Calibur (Becton Dickinson).

\section{ASSAY FOR CYTOKINES}

Serum collected from tested mice were assayed for the level of IL-2, TNF- $\alpha$, and IFN- $\gamma$ using commercially available kits from R\&D systems, with a solid-phase enzyme-linked immunoabsorbent assay (ELISA) as described by the manufacturers.

\section{PRODUCTION OF NITRITE ION}

The amount of $\mathrm{NO}_{2}^{-}$present in fresh serum collected from tested mice were assayed by Griess reagent, using $\mathrm{NaNO}_{2}$ as a standard. Briefly, $50 \mu \mathrm{l}$ of serum was reacted with $50 \mu \mathrm{l}$ of Griess reagent ( $1 \%$ sulfanilamide in $5 \% \mathrm{H}_{3} \mathrm{PO}_{4}-0.1 \%$ naphthalene ethylendiamine dihydrochloride) for $10 \mathrm{~min}$. The absorbance was then read at $540 \mathrm{~nm}$ using a microplate reader.

\section{STATISTICAL ANALYSIS}

Statistical significance was determined by one-way ANOVA employing the computer SPSS statistic package. $P<0.05$ was considered significant.

\section{RESULTS}

\section{ANTITUMOR EFFECT OF GL-BSP ON SARCOMA 180 IN MICE}

In in vivo experiment, mice were implanted with Sarcoma 180 and different dosages of Gl-BPS or physiological saline (model group) were administrated intragastrically for 14 days. Compared with the model group, Gl-BSP 100 and $200 \mathrm{mg} \mathrm{kg}^{-1}$ significantly inhibited growth of Sarcoma 180 by 49.1 and 59.9\%, respectively, with no effect on body weight (Table 1).

\section{EFFECT OF GL-BSP ON PROLIFERATION OF SARCOMA 180 AND PG CELLS IN VITRO}

Gl-BSP did not inhibit Sarcoma 180 and PG cell proliferation in vitro when added directly to the cultured medium (Table 2); but Gl-BSP (50, 100, and $\left.200 \mathrm{mg} \mathrm{kg}^{-1}\right)$-treated serum of S180-bearing mice markedly inhibited S180 or PG cell proliferation (Figure 1).

\section{EFFECT OF GL-BSP ON SPLEEN LYMPHOCYTE PROLIFERATION INDUCED BY CON A AND LPS IN S180-BEARING MICE}

Compared with normal mice, proliferation of spleen lymphocyte induced by Con A and LPS declined significantly in S180-bearing mice administrated with physiological saline (model group), but Gl-BSP administrated intragastrically promoted spleen lymphocytes proliferation induced by Con A and LPS in S180-bearing mice (Table 3).

\section{EFFECT OF GL-BSP ON SPLENIC NK CYTOTOXIC ACTIVITY IN S180-BEARING MICE}

Compared with normal mice, splenic NK cytotoxic activity in model group was significantly lower, reduced from $35.6 \%$ down to $8.3 \%$, while $G l$-BSP $\left(50,100\right.$, and $\left.200 \mathrm{mg} \mathrm{kg}^{-1}\right)$ administrated intragastrically increased the splenic NK cytotoxic activity of S180-bearing mice (Table 4).

\section{EFFECT OF GL-BSP ON PHAGOCYTOSIS BY PERITONEAL MACROPHAGES IN S180-BEARING MICE}

Gl-BSP $\left(50,100\right.$, or $200 \mathrm{mg} \mathrm{kg}^{-1}$ ) could augment the percentage of phagocytosis of NR by peritoneal macrophages in S180-bearing mice (Table 5).

\section{EFFECT OF GL-BSP ON T LYMPHOCYTE SUBPOPULATION IN S180-BEARING MICE}

Compared with normal mice, the percentage of the $\mathrm{CD}^{+}$or $\mathrm{CD}^{+}$subset decreased markedly, while the $\mathrm{CD} 4^{+} / \mathrm{CD}^{+}$ratio increased significantly in the model group. The results indicated that the number of $\mathrm{CD}^{+}$subset decreased more than that of $\mathrm{CD}^{+}{ }^{+}$subset. Compared with the model group, the percentage of the $\mathrm{CD}^{+}$and $\mathrm{CD}^{+}$subset in S180-bearing mice treated with

Table 2 | Effect of GI-BSP on proliferation of Sarcoma 180 cells and PG cells in vitro $(\bar{x} \pm \mathbf{s})$.

\begin{tabular}{llll}
\hline Group & Concentration $\left(\mathbf{m g ~ I}^{-\mathbf{1}}\right)$ & \multicolumn{2}{c}{ Inhibitory ratio (\%) } \\
\cline { 3 - 4 } & & $\begin{array}{l}\text { Sarcoma } \mathbf{1 8 0} \text { cells } \\
(\boldsymbol{n}=\mathbf{7})\end{array}$ & $\begin{array}{l}\text { PG cells } \\
(\boldsymbol{n}=\mathbf{5})\end{array}$ \\
\hline RMPI-1640 & - & 0.0 & 0.0 \\
GI-BSP & 0.1 & 0.2 & 1.4 \\
& 1 & 3.1 & 0.2 \\
& 10 & 1.3 & 0.4 \\
& 100 & 3.3 & 2.0 \\
& 400 & 7.1 & 0.8
\end{tabular}

Table 1 | Antitumor effect of GI-BSP on Sarcoma 180 in BALB/c mice $(n=10, \bar{x} \pm s)$.

\begin{tabular}{|c|c|c|c|c|c|}
\hline \multirow[t]{2}{*}{ Group } & \multirow[t]{2}{*}{ Dose $\left(\mathrm{mg} \mathrm{kg}^{-1} \times\right.$ days $)$} & \multicolumn{2}{|c|}{ Body weight (g) } & \multirow[t]{2}{*}{ Tumor weight (g) } & \multirow[t]{2}{*}{ Inhibitory ratio (\%) } \\
\hline & & Origin & After & & \\
\hline \multirow[t]{3}{*}{ GI-BSP } & $50 \mathrm{mg} \mathrm{kg}^{-1} \times 14$ & $20.9 \pm 0.9$ & $20.4 \pm 0.9$ & $0.84 \pm 0.42$ & 30.7 \\
\hline & $100 \mathrm{mg} \mathrm{kg}^{-1} \times 14$ & $20.5 \pm 0.8$ & $20.5 \pm 1.4$ & $0.61 \pm 0.47^{*}$ & 49.1 \\
\hline & $200 \mathrm{mg} \mathrm{kg}^{-1} \times 14$ & $20.9 \pm 0.8$ & $21.6 \pm 0.8^{* *}$ & $0.48 \pm 0.39 * *$ & 59.9 \\
\hline
\end{tabular}

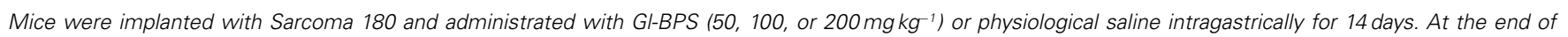
experiment, the tumor were removed and weighted. ${ }^{*} P<0.05,{ }^{*} P<0.01,{ }^{*}{ }^{*} P<0.001 \mathrm{vs}$. model group. 


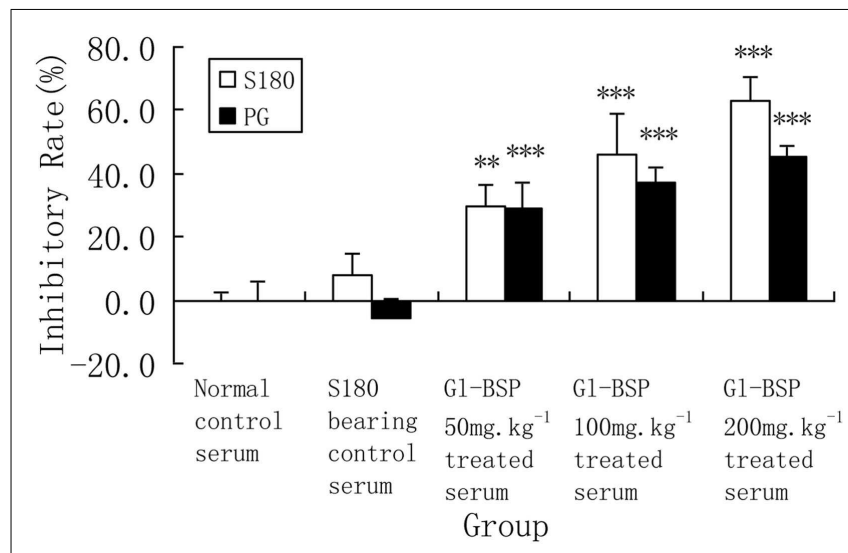

FIGURE 1 | Effect of GI-BSP-treated serum on proliferation of S180 and PG cells in vitro $(\boldsymbol{n}=\mathbf{9}, \overline{\boldsymbol{x}} \pm \mathbf{s})$. Mice were implanted with Sarcoma 180 and GI-BPS (50, 100, or $200 \mathrm{mg} \mathrm{kg}^{-1}$ ) or physiological saline were administrated intragastrically for 14 days. At the end of experiment, blood samples were collected from the orbital vein and the serum was sterilized by filtration. A cell suspension $\left(2 \times 10^{7}\right.$ cell per liter) was made with $5 \%$ FCS RPMI-1640, planted onto 96-well culture plates $(0.1 \mathrm{ml}$ per well), and incubated at $37^{\circ} \mathrm{C}, 5 \% \mathrm{CO}_{2}$ for $24 \mathrm{~h}$. The media was replaced with $0.1 \mathrm{ml}$ of RPMI- 1640 supplemented with $5 \%$ Gl-BSP treated serum 50,100 , or $200 \mathrm{mg} \mathrm{kg}^{-1}$. After $48 \mathrm{~h}$, cells proliferation was estimated by MTT. Data are the mean $\pm \mathrm{SD}$ of three separate experiments. ${ }^{*} P<0.01,{ }^{* *} P<0.001$ vs. S180-bearing control serum (model group).

Table 3 | Effect of GI-BSP on spleen lymphocyte proliferation induced by Con A and LPS in S180-bearing mice $(n=5, \bar{x} \pm s)$.

\begin{tabular}{|c|c|c|c|}
\hline \multirow[t]{2}{*}{ Group } & \multirow[t]{2}{*}{ Dose $\left(\mathrm{mg} \mathrm{kg}^{-1} \times\right.$ days $)$} & \multicolumn{2}{|c|}{ Proliferation ratio $(\%)$} \\
\hline & & Con $A\left(1 \mathrm{mgl}^{-1}\right)$ & LPS $\left(5 \mathrm{mg} \mathrm{l}^{-1}\right.$ \\
\hline Normal & - & $254.0 \pm 8.4$ & $127.0 \pm 8.8$ \\
\hline Model & - & $130.3 \pm 8.3^{\# \# \#}$ & $108.8 \pm 7.6^{\# \#}$ \\
\hline $\mathrm{CY}$ & $30 \mathrm{mg} \mathrm{kg}^{-1} \times 7$ (i.p, q.o.d) & $105.0 \pm 2.1^{* * *}$ & $71.2 \pm 5.7^{* * *}$ \\
\hline \multirow[t]{3}{*}{ GI-BSP } & $50 \mathrm{mg} \mathrm{kg}^{-1} \times 14$ & $184.3 \pm 3.4^{* * *}$ & $115.5 \pm 8.9$ \\
\hline & $100 \mathrm{mg} \mathrm{kg}^{-1} \times 14$ & $230.5 \pm 10.2 * * *$ & $116.8 \pm 0.5$ \\
\hline & $200 \mathrm{mg} \mathrm{kg}^{-1} \times 14$ & $236.4 \pm 6.7^{* * *}$ & $123.4 \pm 5.7^{*}$ \\
\hline
\end{tabular}

S180-bearing mice were administrated intragastrically with GI-BPS $(50,100$, or $200 \mathrm{mg} \mathrm{kg}^{-1}$ ) or physiological saline respectively for 14 days. At the end of experiment, single splenic lymphocytes were adjusted to a concentration of $1 \times 10^{6}$ cells per well in 96-well culture plates with or without ConA $1 \mathrm{mgl}^{-1}$ or LPS $5 \mathrm{mgl}^{\text {H}^{-1}}$, and incubated at $37^{\circ} \mathrm{C}, 5 \% \mathrm{CO}_{2}$ for $72 \mathrm{~h}$. Cell proliferation was estimated based on the method of MTT. \#P<0.01, ${ }^{\# \# P} P<0.001$ model group vs. normal group; ${ }^{*} P<0.05,{ }^{* *} P<0.001$ vs. model group.

Gl-BSP $\left(50,100\right.$, or $\left.200 \mathrm{mg} \mathrm{kg}^{-1}\right)$ was greatly augmented, and the ratio of $\mathrm{CD} 4^{+} / \mathrm{CD} 8^{+}$reduced nearly to that in normal mice (Table 6).

\section{EFFECT OF GL-BSP ON PRODUCTION OF SERUM CYTOKINES IN S180-BEARING MICE}

On the basis of the effect of $G l$-BSP on splenic lymphocytes, NK cells, and peritoneal macrophages, the production of serum cytokines was detected. We found that IL-2, IFN- $\gamma$, and TNF- $\alpha$ in serum were undetectable in normal mice. Only IFN- $\gamma$ in serum
Table 4 | Effect of GI-BSP on splenic NK cytotoxic activity in S180-bearing mice $(n=5, \bar{x} \pm s)$.

\begin{tabular}{llc}
\hline Group & Dose ${\mathbf{~} \mathbf{m g ~ k g}^{-1} \mathbf{x} \text { days) }}$ & Cytotoxicity (\%) \\
\hline Normal & - & $35.6 \pm 2.3$ \\
Model & - & $8.3 \pm 1.7^{\# \#}$ \\
CY & $30 \mathrm{mg} \mathrm{kg}^{-1} \times 7$ (i.p, q. o. d) & $0.6 \pm 0.5^{* * *}$ \\
GI-BSP & $50 \mathrm{mg} \mathrm{kg}^{-1} \times 14$ & $13.8 \pm 1.0^{* *}$ \\
& $100 \mathrm{mg} \mathrm{kg}^{-1} \times 14$ & $21.4 \pm 2.9^{* * *}$ \\
& $200 \mathrm{mg} \mathrm{kg}^{-1} \times 14$ & $30.3 \pm 1.1^{* * *}$ \\
\hline
\end{tabular}

S180-bearing mice were administrated intragastrically with GI-BPS 150,100 , or $200 \mathrm{mg} \mathrm{kg}^{-1}$ ) or physiological saline for 14 days, and the splenic NK cytotoxic activity of mice was examined in a 4-h ${ }^{51} \mathrm{Cr}$ assay. Target cell: YAC-1. Effector: target cell $=40: 1 ;{ }^{\# \#} P<0.001$ model group vs. normal group; ${ }^{*} P<0.01,{ }^{*}{ }^{*} P<0.001$ vs. model group.

Table 5 | Effect of GI-BSP on phagocytosis by peritoneal macrophages in S180-bearing mice $(n=5, \bar{x} \pm s)$.

\begin{tabular}{llc}
\hline Group & Dose $\left(\mathbf{m g ~ k g}^{-\mathbf{1}} \mathbf{x}\right.$ days) & Phagocytosis ratio (\%) \\
\hline Normal & - & $100.1 \pm 11.0$ \\
Model & - & $48.2 \pm 5.0^{\# \# \#}$ \\
Gl-BSP & $50 \mathrm{mg} \mathrm{kg}^{-1} \times 14$ & $75.0 \pm 4.0^{* *}$ \\
& $100 \mathrm{mg} \mathrm{kg}^{-1} \times 14$ & $134.1 \pm 7.8^{* * *}$ \\
& $200 \mathrm{mg} \mathrm{kg}^{-1} \times 14$ & $141.6 \pm 27.8^{* * *}$
\end{tabular}

S180-bearing mice were administrated intragastrically with GI-BPS 150,100 , or $200 \mathrm{mg} \mathrm{kg}^{-1}$ ) or physiological saline respectively for 14 days. At the end of experiment, the activity of peritoneal macrophages was measured by NR phagocytosis assay. ${ }^{\# \#} P<0.001$ model group vs. normal group; ${ }^{*} P<0.01,{ }^{* *} P<0.001$ vs. model group.

was detectable in S180-bearing mice. The serum levels of IL-2, IFN- $\gamma$, and TNF- $\alpha$ were markedly increased in S180-bearing mice administrated with $\mathrm{Gl}$-BSP $\left(200 \mathrm{mg} \mathrm{kg}^{-1}\right)$, compared with that in S180-bearing control mice administrated with physiological saline (Table 7).

\section{ANTIBODY NEUTRALIZATION}

To determine whether the growth inhibition in Sarcoma 180 cells or PG cells induced by $\mathrm{Gl}$-BSP $200 \mathrm{mg} \mathrm{kg}^{-1}$-treated serum was related to the cytokines released from immune system activated by $\mathrm{Gl}$-BSP in S180-bearing tumor mice. Serums collected from mice in all groups were preincubated with one or two cytokineneutralizing antibodies before addition to cell cultures. Neutralization with anti-TNF- $\alpha$ apparently diminished S180 or PG cell lines growth inhibition induced by $G l$-BSP $200 \mathrm{mg} \mathrm{kg}^{-1}$-treated serum, and a similar result was obtained by use of anti-IFN$\gamma$. Blocking effect was noted in the combination of anti-TNF- $\alpha$ and anti-IFN- $\gamma$, which reduced the inhibition rate from 55.6 or $45.1 \%$ (before neutralization in S180 or PG cell lines) down to 11 or $15.8 \%$, respectively. However, the cytokine antibodies used above did not completely block growth inhibition induced by the $\mathrm{Gl}$-BSP $200 \mathrm{mg} \mathrm{kg}^{-1}$-treated serum of S180-bearing mice (Table 8). 
Table 6 | Effect of GI-BSP on T lymphocyte subpopulation in S180-bearing mice $(n=3, \bar{x} \pm \mathrm{s})$.

\begin{tabular}{lllcl}
\hline Group & Dose $\left(\mathbf{m g ~ k g}^{-\mathbf{1}} \mathbf{x}\right.$ days) & $\mathbf{C D 4}^{+}$(\%) & CD8 $^{+}$(\%) & CD4 $^{+} / \mathbf{C D 8}^{+}$ \\
\hline Normal & - & $33.67 \pm 0.94$ & $18.14 \pm 1.46$ & $1.86 \pm 0.11$ \\
Model & - & $20.98 \pm 0.26^{\# \# \#}$ & $9.46 \pm 0.48^{\# \# \#}$ \\
Gl-BSP & $50 \mathrm{mg} \mathrm{kg}^{-1} \times 14$ & $22.73 \pm 0.31^{* *}$ & $11.27 \pm 0.55^{* *}$ & $2.22 \pm 0.12^{\# \# \#}$ \\
& $100 \mathrm{mg} \mathrm{kg}^{-1} \times 14$ & $22.99 \pm 0.92^{* *}$ & $11.95 \pm 0.64^{* * *}$ & $2.02 \pm 0.09^{*}$ \\
& $200 \mathrm{mg} \mathrm{kg}^{-1} \times 14$ & $23.81 \pm 1.08^{* * *}$ & $12.14 \pm 0.05^{* * *}$ & $1.93 \pm 0.03^{* *}$ \\
\hline
\end{tabular}

S180-bearing mice were administrated intragastrically with GI-BPS (50, 100, or $200 \mathrm{mg} \mathrm{kg}^{-1}$ ) or physiological saline respectively for 14 days; single splenic lymphocytes were labeled with anti-mouse CD4-FITC and anti-mouse CD8-PE. The CD4 and CD8 T-cell subpopulations were analyzed by flow cytometry using a FACS Calibur. ${ }^{\# \# \#} P<0.001$ model group vs. normal group; ${ }^{*} P<0.05,{ }^{*} P<0.01,{ }^{* * *} P<0.001$ vs. model group.

Table 7 | Effect of GI-BSP on Production of Serum Cytokines and NO in S180-bearing mice $(n=10, \bar{x} \pm s)$.

\begin{tabular}{|c|c|c|c|c|c|}
\hline \multicolumn{2}{|c|}{ Group } & \multirow{2}{*}{ 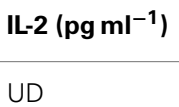 } & \multirow{2}{*}{$\begin{array}{l}\text { IFN- } \gamma\left(\mathbf{p g ~ m l}^{-1}\right) \\
\text { UD }\end{array}$} & \multirow{2}{*}{$\begin{array}{l}\text { TNF- } \alpha\left(\mathbf{p g ~ m l}^{-1}\right) \\
\text { UD }\end{array}$} & \multirow{2}{*}{$\begin{array}{c}\mathbf{N O}^{2-}(\boldsymbol{\mu M}) \\
6.78 \pm 4.94\end{array}$} \\
\hline Normal control & - & & & & \\
\hline S180-bearing control & - & UD & $11.73 \pm 3.53$ & UD & $4.82 \pm 3.74$ \\
\hline \multirow{2}{*}{ GI-BSP } & $100 \mathrm{mg} \mathrm{kg}^{-1}$ & UD & $20.13 \pm 2.93 * *$ & $20.62 \pm 16.8$ & $17.32 \pm 5.30^{* *}$ \\
\hline & $200 \mathrm{mg} \mathrm{kg}^{-1}$ & $3.4 \pm 2.46 * * *$ & $67.42 \pm 5.47^{* * *}$ & $72.58 \pm 33.40^{* * *}$ & $35.63 \pm 10.0 * * *$ \\
\hline
\end{tabular}

S180-bearing mice were administrated intragastrically with GI-BPS $\left(50,100,200 \mathrm{mg} \mathrm{kg}^{-1}\right)$ or physiological saline respectively for 14 days. At the end of experiment, the serum was collected and the production of serum cytokines was detected by ELISA. Serum NO level was measured by Griess reagent. ${ }^{* *} P<0.01,{ }^{* * *} P<0.001$ vs. S180-bearing control; UD: undetected.

\section{EFFECT OF GL-BSP-TREATED SERUM WITH OR WITHOUT HEAT INACTIVATION ON PROLIFERATION OF S180 CELLS IN VITRO}

We found that the Gl-BSP-treated serum of S180-bearing mice had the different effects on Sarcoma 180 cell proliferation in vitro. After $G l$-BSP $200 \mathrm{mg} \mathrm{kg}^{-1}$-treated serum underwent heat-inactive at $56^{\circ} \mathrm{C}$ for $30 \mathrm{~min}$, the inhibition rate reduced from $57.1 \%$ down to 10.9\%; while $G l$-BSP $50 \mathrm{mg} \mathrm{kg}^{-1}$ and $100 \mathrm{mg} \mathrm{kg}^{-1}$-treated serum with pretreatment at $56^{\circ} \mathrm{C}$ for $30 \mathrm{~min}$ did not show significantly effect on the proliferation of Sarcoma 180 cells in vitro (Figure 2).

\section{DISCUSSION}

In the present study, we investigated the antitumor activity of the polysaccharides isolated from broken-spore of G. lucidum, GlBSP. The spore of G. lucidum has a especially tough wall. Recently some researchers indicated that broken spores have more activities than non-broken spores (Zhu et al., 2000; Sliva et al., 2003; Wang et al., 2005). In our research, we also compared the antitumor and immunomodulatory effects of non-broken spore polysaccharides ( $G l$-SP) and $G l$-BSP extracted from G. lucidum. We found that both Gl-SP and Gl-BSP could inhibit the tumor growth and improve the immune function in tumor-bearing mice in vivo, but Gl-BSP showed much higher bioactivities than Gl-SP (data not showed).

$\beta$-Glucans are one of the most abundant forms of polysaccharides found inside the cell wall of bacteria and fungus. All $\beta$-glucans are glucose polymers linked together by a $1 \rightarrow 3$ linear $\beta$-glycosidic chain core and they differ from each other by their length and branching structures. Fungal $\beta$-glucan is $\beta$-Dglucose linked to one another by $1 \rightarrow 3$ glycosidic chain with $1 \rightarrow 6$ glycosidic branches whereas bacterial $\beta$-glucans have $1 \rightarrow 4$ side branches. Bacterial endotoxin such as lipopolysaccharide (LPS) is a potent immune stimulator and exogenous pyrogen, which causes fever, shock, and disseminated intravascular coagulation. Endotoxin contamination can lead to false positive results in immune tests and toxicity (Chan et al., 2009; Gertsch et al., 2011). Hence, we evaluated the quantity of endotoxin in Gl-BSP by limulus amebocytes lysate assay, which was less than $0.01 \mathrm{EU} \mathrm{mg}^{-1}$. This data indicated that endotoxin contamination in Gl-BSP used in this study was negligible. It should be noted that Gl-BSP is a complex consisted of polysaccharides and peptide, but endotoxin has no peptide. It is therefore possible that peptide in Gl-BSP may be involved in some of the bioactivity of Gl-BSP. Furthermore, there was no evident of toxic or side effect observed in Gl-BSP treated mice during our experiments.

Kuang et al. (2007) used G. lucidum broken-spore powder combined with chemotherapy in the treatment of 28 patients of malignant neoplastic diseases. The patients were orally treated with $0.9 \mathrm{~g}$ of $\mathrm{G}$. lucidum broken-spore at a time, three times a day, for 6 weeks, combined with chemotherapy at the same time. Qi et al. (1999) used G. lucidum spore powder combined with chemotherapy in the treatment of 100 patients of malignant tumor. The patients were treated with $1 \mathrm{~g}$ of G. lucidum spore at a time, three times a day, for a month, combined with chemotherapy at the same time. The above clinical trials demonstrated that G. lucidum spore's adjuvant efficacy in treating cancer patients by strengthening the immunity and decreasing toxic side effects caused by chemotherapy, compared with chemotherapy alone.

Extraction ratio of polysaccharides from G. lucidum spore is about 2.4\% (Lin et al., 2003). A dose of G. lucidum polysaccharides 
about $0.07 \mathrm{~g}$ per day in human is equal to about $10 \mathrm{mg} \mathrm{kg}^{-1}$ per day in mice, according to the equivalent conversion of dose between species (Mizuno et al., 1995). G. lucidum is approved by Ministry of Health in China as a new drug resource. Thus, less than $100 \mathrm{mg} \mathrm{kg}^{-1} \mathrm{Gl}$-BSP may represent a real dose and further study is needed to confirm this assumption.

The present results showed that Gl-BSP inhibited the growth of implanted Sarcoma 180 markedly. On the basis of the preceding in vivo results, we examined the direct in vitro effects of $G l$-BSP or serum from $G l$-BSP treated mice in Sarcoma 180 and PG cell cultures. We found that Gl-BSP could not inhibit their proliferation in vitro indicating that $G l$-BSP had no direct cytotoxicity on tumor cells. In contrast, $G$-BSP $\left(50,100\right.$, or $\left.200 \mathrm{mg} \mathrm{kg}^{-1}\right)$-treated serum could significantly inhibit Sarcoma 180 cells and PG cells proliferation. Our previous studies imply that Gl-BSP can potentiate

Table 8 | Effect of GI-BSP-treated serum of S180-bearing mice preincubated with cytokine-neutralizing antibodies on the proliferation of $S 180$ and PG cells $(n=10, \bar{x} \pm s)$.

\begin{tabular}{llc}
\hline \multirow{2}{*}{ Group } & \multicolumn{2}{c}{ Inhibitory ratio (\%) } \\
\cline { 2 - 3 } & $\mathbf{S 1 8 0}$ & PG \\
\hline $\begin{array}{l}\text { GI-BSP 200 } \mathrm{mg} \mathrm{kg}^{-1} \text {-treated serum } \\
\text { alone }\end{array}$ & $55.6 \pm 1.7$ & $45.1 \pm 2.4$ \\
$\begin{array}{l}\text { GI-BSP 200 } \mathrm{mg} \mathrm{kg}^{-1} \text {-treated } \\
\text { serum + anti-TNF- } \alpha\end{array}$ & $32.5 \pm 1.2^{* * *}$ & $29.0 \pm 4.0^{* * *}$ \\
$\begin{array}{l}\text { GI-BSP 200 } \mathrm{mg} \mathrm{kg}^{-1} \text {-treated } \\
\text { serum + anti-IFN- } \gamma \\
\text { GI-BSP 200 } \mathrm{mg} \mathrm{kg}^{-1} \text {-treated } \\
\text { serum + anti-TNF- } \alpha+\text { anti-IFN- } \gamma\end{array}$ & $45.0 \pm 2.4^{* * *}$ & $34.1 \pm 3.0^{* * *}$ \\
\hline
\end{tabular}

GI-BSP $200 \mathrm{mg} \mathrm{kg}^{-1}$-treated serum of S180-bearing mice preincubated with or without various cytokine-neutralizing antibodies (anti-TNF-, $150 \mathrm{ng} \mathrm{ml}^{-1}$, and/or anti-IFN- $\gamma, 150 \mathrm{ng} \mathrm{m}^{-1}$ ) at $37^{\circ} \mathrm{C}$ for 90 min before addition to $S 180$ or PG cells cultures. Data are the mean $\pm S D$ of 3 separate experiments. ${ }^{* *} P<0.001$ vs. Gl-BSP $200 \mathrm{mg} \mathrm{kg}^{-1}$-treated serum. immunomodulatory activity in vivo that contributes significantly to its antitumor activity (Wang et al., 2005).

We investigated the effect of Gl-BSP on splenic lymphocyte, spleen NK cell and peritoneal macrophage activities in S180bearing $\mathrm{BALB} / \mathrm{c}$ mice in vivo. The results in vivo were consistent with those in vitro. Gl-BSP promoted the spleen lymphocytes proliferation induced by Con A or LPS, enhanced NK cytotoxic activity, augmented the percentage of phagocytosis of NR by macrophages, and increased the percentage of the $\mathrm{CD}^{+}$or $\mathrm{CD}^{+}$subset in S180-bearing BALB/c mice. Gl-BSP showed immunomodulatory activities in improving the immunorepressive state of tumor-bearing mice. The mean serum concentration of TNF- $\alpha$, IFN- $\gamma$ and NO apparently increased in Gl-BSP-treated groups. TNF- $\alpha$ and IFN- $\gamma$ play important roles in depressing tumor cell growth and inducing apoptosis of tumor cells (Spanaus et al., 1998; Smyth and Johnstone, 2000; Shin et al., 2001; Ruiz de Almodovar et al., 2004). They are potential endogenous products in mediating the effect of Gl-BSP on the immune system in vivo. Anti-TNF- $\alpha$ apparently diminished the growth inhibitory effect of serum from Gl-BSP $200 \mathrm{mg} \mathrm{kg}^{-1}$ treated S180-bearing mice in S180 or PG cell lines. Similar results were obtained using anti-IFN- $\gamma$. Greater neutralization effect was noted in the combination of anti-TNF- $\alpha$ and anti-IFN- $\gamma$ in reducing the inhibition rate of serum from $G l$-BSP $200 \mathrm{mg} \mathrm{kg}^{-1}$-treated S180-bearing mice $(55.6 \%$ before neutralization to $11.3 \%$ in $\$ 180$ cell lines and from $45.1 \%$ before neutralization to $15.8 \%$ in PG cell lines respectively). However, the cytokine antibodies used above did not completely block growth inhibition of serum from $\mathrm{Gl}$ BSP $200 \mathrm{mg} \mathrm{kg}^{-1}$-treated S180-bearing mice in S180 or PG cell lines suggesting other bioactive products in the serum, such as NO and complements may also play a role.

There may be other active ingredients in the serum from GlBSP-treated mice, such as NO, activated complement C3 and metabolized substance of Gl-BSP. NO has been identified as the major effector molecule involved in the destruction of tumor cells by activated macrophages (Stuehr and Nathan, 1989; Keller et al., 1990). Also, NO has been recognized as an important messenger in diverse pathophysiological functions, including neuronal



FIGURE 2 | Effect of $\mathrm{GI}$-BSP-treated serum with or without $30 \mathrm{~min} 56^{\circ} \mathrm{C}$ heat pretreatment on proliferation of $\mathrm{S} 180$ cells in vitro ( $n=10, \bar{x} \pm \mathrm{s}$ ). ${ }^{*} P<0.05,{ }^{*} P<0.01,{ }^{* *} P<0.001$ vs. normal control. 
transmission, vascular relaxation, immune modulation, and cytotoxicity against tumor cells (Lowenstein et al., 1994). NO being a gaseous free radical, has a short half life and is rapidly metabolized to nitrate $\left(\mathrm{NO}_{3}^{-}\right)$and nitrite $\left(\mathrm{NO}_{2}^{-}\right)$. So it is difficult to measure $\mathrm{NO}$ directly, nitrate or nitrite are measured normally as indices of NO production (Coleman, 2001). We observed the mean serum concentration of NO increased in Gl-BSP -treated groups, especially in Gl-BSP $200 \mathrm{mg} \mathrm{kg}^{-1}$-treated group. As a result, NO in serum might be another inhibitory component in suppressing the growth of Sarcoma 180 or PG cells in vitro. Considering the activity of cytokines and NO, serum derived from all tested mice did not be heat-inactive at $56^{\circ} \mathrm{C}$ for $30 \mathrm{~min}$ in the former experiments. We compared the different effect on proliferation of $\mathrm{S} 180$ cells in vitro between $G l$-BSP-treated serum with and without pretreatment at $56^{\circ} \mathrm{C}$ for $30 \mathrm{~min}$. The result showed some activated substances lost theirs activity after $G l$-BSP-treated serum underwent heat-inactive at $56^{\circ} \mathrm{C}$ for $30 \mathrm{~min}$.

Although effect of humoral immunity to tumor is not as important as that of cellular immune responses against tumor, IgM and IgG1 (IgG3) which might be in Gl-BSP-treated serum could mediate cytolytic activity with the help of component C3. A polysaccharide isolated from spores of G. lucidum showed significant effect in enhancing the serum component C3 level in mice but

\section{REFERENCES}

Bao, X., Duan, J., Fang, X., and Fang, J. (2001a). Chemical modifications of the $(1 \rightarrow 3)$-alpha-D-glucan from spores of Ganoderma lucidum and investigation of their physicochemical properties and immunological activity. Carbohydr. Res. 336, 127-140.

Bao, X., Fang, J., and Li, X. (2001b). Structural characterization and immunomodulating activity of a complex glucan from spores of Ganoderma lucidum. Biosci. Biotechnol. Biochem. 65, 2384-2391.

Bao, X. F., and Fang, J. N. (2001). Studies on difference between sporodermbroken and nonbroken spores of Ganoderma lucidum (Leyss. ex Fr.) Karst. by polysaccharide analysis. Zhong guo Zhong Yao Za Zhi 26, 326-328.

Bao, X. F., Dong, Q., and Fang, J. N. (2000). Structure and conformation behavior of a glucan from spores of Ganoderma lucidum (Fr.) Karst. Sheng Wu Ниа Xие Yu Sheng Wu Wu Li Xue Bao 32, 557-561.

Chan, G. C. F., Chan, W. K., and Sze, D. M. Y. (2009). The effects of $\beta$-glucan on human immune and cancer cells. J. Hematol. Oncol. 2, 25.

Coleman, J. W. (2001). Nitric oxide in immunity and inflammation. Int. Immunopharmacol. 1 , 1397-1406.

Gertsch, J., Viveros-Paredes, J. M., and Taylor, P. (2011). Plant immunostimulants-scientific paradigm or myth? J. Ethnopharmacol. $136,385-391$.

Hsu, M. J., Lee, S. S., Lee, S. T., and Lin, W. W. (2003). Signaling mechanisms of enhanced neutrophil phagocytosis and chemotaxis by the polysaccharide purified from Ganoderma lucidum. Br. J. Pharmacol. 139, 289-298.

Hsu, M. J., Lee, S. S., and Lin, W. W. (2002). Polysaccharide purified from Ganoderma lucidum inhibits spontaneous and Fas-mediated apoptosis in human neutrophils through activation of the phosphatidylinositol 3 kinase/Akt pathways. J. Leuokoc. Biol. 72, 207-216.

Hu, Y. H., and Lin, Z. B. (1999). Effects of polysaccharides isolated from mycelia of Ganoderma lucidum on HL-60 cell apoptosis. Acta Pharmacol. Sin. 34, 264-268.

Keller, R., Keist, R., Wechsler, A., Leist, T. P., and van der Meide, P. H. (1990). Mechanisms of macrophage-mediated tumor cell killing: a comparative analysis of the roles of reactive nitrogen intermediates and tumor necrosis factor. Int. J. Cancer 46, 682-686.

Kim, H. S., Kacew, S., and Lee, B. M. (1999). In vitro chemopreventive effects of plant polysaccharides (Aloe barbadendis miller, Lentis edodes, Ganoderma lucidum and Coriolus versicolor). Carcinogenesis 20, 1637-1640.

had a small effect in increasing the production of antibodies against sheep red blood cells in mice (Bao et al., 2001a). Further investigation is necessary to determine whether or not the effect of Gl-BSP on the complement system and humoral immune responses may also contribute to the antitumor mechanism of Gl-BSP.

In summary, we demonstrated that Gl-BSP inhibited the tumor growth and restored the depressed immune response in tumorburdened mice to the normal or near normal level. The antitumor activity of Gl-BSP may be related to the activation of the immune response of the host organism by the stimulation of NK cells, T cells, and macrophage-dependent immune system responses. Our results provide a clue that Gl-BSP may be considered as an efficacious adjacent immunopotentiating therapy in the treatment of tumor where immunosuppression occurs. Further studies are required to elucidate and confirm the effectiveness of restoring the immune response by GL-BSP in the treatment of tumor.

\section{ACKNOWLEDGMENTS}

We thank Professor Sai-Zhen Wang and Shu-Qian Lin from Fuzhou Institute of Green Valley Bio-Pharm Technology for their support in providing $G l$-BSP and Gl-SP.

Kuang, J. M., Wang, J. W., and Kuang, J. M. (2007). Curative effects of combination of Ganoderma lucidum broken-spore powder and chemotherapy on malignant tumors. Shandong Med. J. 47, 59-60.

Lee, S. H., Lee, P. L., Chen, C. F., Wang, S. Y., and Chen, K. Y. (2003). Antitumor effects of polysaccharides of Ganoderma lucidum (Curt.: Fr.) P. Karst. (Ling Zhi, Reishi Mushroom) (Aphyllphoromycetideae). Int. J. Med. Mushrooms 2003, 1-16.

Lin, S. Q., Wang, S. Z., Lin, Z. B., and Lin, Y. X. (2003). Isolation and identification of active components of Ganoderma lucidum cultivated with grass and wood log I. Extraction, purification and characterization of glycopeptides. Chin. Tradit. Herb. Drugs 34, 33-35.

Lin, Z. B. (2001). Modern Research of Ganoderma lucidum, 2nd Edn. Beijing: Beijing Medical University Press, 219-283.

Lin, Z. B., and Zhang, H. N. (2004). Antitumor and immunoregulatory activities of Ganoderma lucidum and its possible mechanisms. Acta Pharmacol. Sin. 25, 1387-1395.

Liu, G. T. (1999). Pharmacology and clinical application of the spores of Ganoderma lucidum (Curt:Fr.) P. Karst. and mycelium of Ganoderma capense (Lloyd) Teng. (Aphyllophromcitideae). Int. J. Med. Mushrooms 1, 63-67.
Liu, X., Yuan, J. P., Chung, C. K., and Chen, X. J. (2002). Antitumor activity of the sporoderm-broken germinating spores of Ganoderma lucidum. Cancer Lett. 182, 155-161.

Lowenstein, C. F., Dinerman, J. L., and Snyder, S. H. (1994). Nitric oxide: a physiologic messenger. Ann. Intern. Med. 120, 227-237.

Lu, Q. Y., Jin, Y. S., Zhang, Q., Zhang, Z., Heber, D., Go, V. L., Li, F. P., and Rao, J. Y. (2004). Ganoderma lucidum extracts inhibit growth and induce actin polymerization in bladder cancer cells in vitro. Cancer Lett. 16, 9-20.

Miyazaki, T., and Nishijima, M. (1981). Studies on fungal polysaccharides. XXVII. Structural examination of a water-soluble, antitumor polysaccharide of Ganoderma lucidum. Chem. Pharm. Bull. 29, 3611-3616.

Mizuno, T., Sakai, T., and Chihara, G. (1995). Health foods and medicinal usages of mushrooms. Food Rev. Int. 11, 69-81.

Qi, Y. F., Li, X. R., Yan, M., Liu, A., Jiao, Z. H., and Liu, Y. (1999). Clinical observation of treating digestive system tumor with Ganoderma lucidum spore powder as adjuvant chemotherapy. Chin. J. Integr. Med. 19, 554-555.

Ruiz de Almodovar, C., Lopez-Rivas, A., and Ruiz-Ruiz, C. (2004). Interferon-gamma and TRAIL in human breast tumor cells. Vitam. Horm. 67, 291-318. 
Sakagami, H., Aoki, T., Simpson, A., and Tanuma, S. (1991). Induction of immunopotentiation activity by a protein-bound polysaccharide, PSK. Anticancer Res. 11, 993-999.

Shin, E. C., Ahn, J. M., Kim, C. H., Choi, Y., Ahn, Y. S., Kim, H., Kim, S. J., and Park, J. H. (2001). IFN-gamma induces cell death in human hepatoma cells through a TRAIL/death receptormediated apoptotic pathway. Int. J. Cancer 93, 262-268.

Sliva, D., Labarrere, C., Slivova, S., Sedlak, M., Lloyd, F. P. Jr., and Ho, N. W. (2002). Ganoderma lucidum suppresses motility of highly invasive breast and prostate cancer cells. Biochem. Biophys. Res. Commun. 298, 603-612.

Sliva, D., Sedlak, M., Slivova, V., Valachovicova, T., Lloyd, F. P. Jr., and Ho, N. W. (2003). Biologic activity of spores and dried powder from Ganoderma lucidum for the inhibition of highly invasive human breast and prostate cancer cells. J. Altern. Complement. Med. 9, 491-497.

Smyth, M. J., and Johnstone, R. W. (2000). Role of TNF in lymphocytemediated cytotoxicity. Microsc. Res. Tech. 50, 196-208.

Sone, Y., Okuda, R., Wada, N., Kishida, E., and Misaki, A. (1985). Structure and antitumor activities of polysaccharides isolated from fruiting body and the growing culture of mycelium of Ganoderma lucidum. Agric. Biol. Chem. 49, 2641-2653.

Spanaus, K. S., Schlapbach, R., and Fontana, A. (1998). TNF- $\alpha$ and IFN$\gamma$ render microglia sensitive to Fas ligand-induced apoptosis by induction of Fas expression and downregulation of Bcl-2 and Bcl-xL. Eur. J. Immunol. 28, 4398-4408.

Stuehr, D. J., and Nathan, C. F. (1989). Nitric oxide: a macrophage product responsible for cytostasis and respiratory inhibition in tumor target cells. J. Exp. Med. 169, 1543-1555.

Susan, W. S., Leung, K. Y., Yeung, Y. L., Siow, R., and Man, Y. K. (2002). "Lingzhi (Ganoderma) research the past, present and future perspectives," in Ganoderma: Genetics, Chemistry, Pharmacology, and Therapeutics, ed. Z. B. Lin (Beijing: Beijing Medical University Press), 1-9.

Wang, P. Y., Wang, S. Z., Lin, S. Q., and Lin, Z. B. (2005). Comparison of the immunomodulatory effects of spore polysaccharides and broken spore polysaccharides isolated from Ganoderma lucidum on murine splenic lymphocytes and peritoneal macrophages in vitro. Beijing Da Xue Xue Bao 37, 569-574.

Wang, S. Y., Hsu, M. L., Hsu, H. C., Tzeng, C. H., Lee, S. S., Shiao, M. S., and Ho, C. K. (1997). The antitumor effect of Ganoderma Lucidum is mediated by cytokines released from activated macrophages and T lymphocytes. Int. J. Cancer 70, 699-705.

Wang, Y. Y., Khoo, K. H., Chen, S. T., Lin, C. C., Wong, C. H., and Lin, C. H. (2002). Studies on the immuno-modulating and antitumor activities of Ganoderma lucidum (Reishi) polysaccharides: functional and proteomic analyses of a fucose-containing glycoprotein fraction responsible for the activities. Bioorg. Med. Chem. 10, 1057-1062.

Wasser, S. P. (2002). Medicinal mushrooms as a source of antitumor and immunomodulating polysaccharides. Appl. Microbiol. Biotechnol. 60, 258-274.

Xia, D., Lin, Z. B., Li, R. Z., and He, Y. Q. (1989). Effects of Ganoderma polysaccharides on immune function in mice. Yao Xue Xue Bao. 21 , 533-537.

Yan, J., Vetvicka, V., Xia, Y., Coxon, A. Carroll, M. C., Mayadas, T. N., and Ross, G. D. (1999). Beta-glucan, a "specific" biologic response modifier that uses antibodies to target tumors for cytotoxic recognition by leukocyte complement receptor type 3 (CD11b/CD18). J. Immunol. 163 3045-3052.

Yang, X. L., Zhu, H. S., Xu, J. L., and Kuang, Q. (1997). Antitumor activity of the Ganoderma Lucidum spore alcohol extract in vitro. J. Beijing Inst. Technol. 6, 336-340.

You, Y. H., and Lin, Z. B. (2002). Protective effects of Ganoderma lucidum polysaccharides peptide on injury of macrophages induced by reactive oxygen species. Acta Pharmacol. Sin. 23, 787-791.

Zhang, G. L., Wang, Y. H., Ni, W., Teng, H. L., and Lin, Z. B. (2002). Hepatoprotective role of Ganoderma lucidum polysaccharide against BCG-induced immune liver injury in mice. World J. Gastroenterol. 8, 728-733.

Zhang, H. N., and Lin, Z. B. (2003). Prevention of low-dose of strptozotocin-induced autoimmune diabetic mice with Ganoderma lucidum polysaccharides. Natl. Med. J. China. 83, 1999-2000.

Zhang, Q. H., and Lin, Z. B. (1999). The antitumor activity of Ganoderma lucidum polysaccharides is related to tumor necrosis factor- $\alpha$ and interferon- $\gamma$. Int. J. Med. Mushrooms 1, 207-215.

Zhu, H. S., Yang, X. L., Wang, L. B., Zhao, D. X., and Chen, L. (2000). Effects of extracts from sporoderm-broken spores of Ganoderma lucidum on HeLa cells. Cell Biol. Toxicol. 16, 201-206.

Conflict of Interest Statement: The authors declare that the research was conducted in the absence of any commercial or financial relationships that could be construed as a potential conflict of interest.

Received: 12 December 2011; accepted: 24 June 2012; published online: 13 July 2012. Citation: Wang P-Y, Zhu X-L and Lin $Z-B$ (2012) Antitumor and immunomodulatory effects of polysaccharides from broken-spore of Ganoderma lucidum. Front. Pharmacol. 3:135. doi: 10.3389/fphar.2012.00135 This article was submitted to Frontiers in Ethnopharmacology, a specialty of Frontiers in Pharmacology.

Copyright (c) 2012 Wang, Zhu and Lin. This is an open-access article distributed under the terms of the Creative Commons Attribution License, which permits use, distribution and reproduction in other forums, provided the original authors and source are credited and subject to any copyright notices concerning any third-party graphics etc. 